\title{
INFLUÊNCIA DAS CONDIÇÕES DE ARMAZENAMENTO DO VÍRUS INFLUENZA NA DETECÇÃO POR RT-qPCR E ISOLAMENTO VIRAL
}

\section{INFLUENCE OF STORAGE CONDITIONS OF INFLUENZA VIRUS ON VIRUS DETECTION BY RT-qPCR AND VIRAL ISOLATION}

\author{
Vanessa Haach ${ }^{1}$ \\ Danielle Gava ${ }^{*}$ \\ Arlei Coldebella ${ }^{2}$ \\ Rejane Schaefer ${ }^{2}$ \\ ${ }^{1}$ Bolsista PIBIC/CNPq na Embrapa Suínos e Aves, Concórdia, SC, Brasil. \\ ${ }^{2}$ EMBRAPA Suínos e Aves, Concórdia, SC, Brasil. \\ *Autora para correspondência - danielle.gava@embrapa.br
}

\section{Resumo}

A infecção de suínos pelo vírus influenza causa perdas significativas na suinocultura e a doença tem implicações consideráveis para a saúde pública. Dessa forma, a rápida detecção viral em amostras biológicas de suínos é importante para a vigilância da influenza. Para o diagnóstico, as condições de manutenção das amostras biológicas (modo de acondicionamento, temperatura e período de acondicionamento), desde a colheita das amostras de suínos até o envio ao laboratório, podem interferir negativamente na detecção viral. Neste estudo foi analisada a viabilidade de uma amostra do vírus influenza A H1N1/2009 isolada de suínos, mantida em diferentes modos de acondicionamento (meio comercial UTM, meio in house VTM e sem meio de manutenção) e diferentes temperaturas $\left(4,23\right.$ e $\left.37^{\circ} \mathrm{C}\right)$ por um período de até 120 horas. As amostras foram avaliadas por RT-qPCR e isolamento em ovos embrionados. Foram observados efeitos significativos $(\mathrm{p}<0,05)$ para o modo e período de acondicionamento e da interação entre esses dois fatores com a carga viral. Dessa forma, as amostras biológicas enviadas para diagnóstico de influenza devem ser armazenadas, preferencialmente, em meio de manutenção viral a $4{ }^{\circ} \mathrm{C}$ e o tempo decorrido entre a colheita da amostra e a chegada ao laboratório deve ser de, no máximo, três dias.

Palavras-chave: diagnóstico; influenza; suínos; viabilidade viral.

\begin{abstract}
Influenza virus infection in pigs causes significant losses for the swine industry and concerns for the public health. Therefore, rapid virus detection is important for influenza surveillance in pigs. Storage conditions (such as medium, temperature, and time) of the biological samples are very important for
\end{abstract}


the diagnosis because they can negatively interfere with the viral detection. In this study, influenza virus viability was evaluated in different storage media (UTM commercial medium, "in house" VTM medium, and without storage medium), temperature $\left(4,23\right.$ and $37^{\circ} \mathrm{C}$ ), and storage time (up to 120 hours). Samples were evaluated by RT-qPCR and isolation in embryonated chicken eggs. Significant effects $(p<0.05)$ were observed for the media and time besides the interaction between the two factors with the viral load. In conclusion, biological samples of pigs sent for influenza diagnosis should be stored, preferably in viral maintenance medium at $4{ }^{\circ} \mathrm{C}$, and the time estimated between the sample collection until the arrival in the laboratory should be less than three days.

Keywords: diagnosis; influenza; swine; viral viability.

Recebido em: 07 de maio de 2017.

Aceito em: 19 de março de 2018.

\section{Introdução}

O vírus influenza A (FLUAV) é um dos principais agentes etiológicos envolvidos em casos de infecção respiratória aguda em suínos, ocasionando prejuízos à suinocultura devido à perda de peso dos animais e aumento do custo de produção pelo uso de antimicrobianos para controlar infecções bacterianas secundárias ${ }^{(1)}$. Embora o vírus influenza seja considerado endêmico na maioria dos países produtores de suínos, surtos da doença começaram a ser registrados globalmente a partir de 2009, associados à infecção pelo vírus pandêmico H1N1 $(\mathrm{H} 1 \mathrm{~N} 1 / 2009)^{(2)}$. No Brasil, apesar de relatos da presença do vírus em suínos já terem sido registrados anteriormente ${ }^{(3,4)}$, surtos de doença respiratória começaram a ser mais frequentes a partir de 2009, sendo o vírus H1N1/2009 identificado nesses $\operatorname{casos}^{(5,6)}$. A partir de 2011, novos vírus influenza dos subtipos virais H1N2 e H3N2 começaram a ser também detectados em casos clínicos de infecção respiratória aguda em suínos no Brasil ${ }^{(7,8)}$.

Para o diagnóstico rápido de influenza, amostras biológicas (secreção nasal e tecido pulmonar) de suínos são testadas por RT-PCR para detectar um gene conservado (gene da matriz) do FLUAV ${ }^{(9,10)}$. Embora o ensaio de RT-PCR seja um método rápido e bastante sensível, detecta somente o RNA viral, não determinando se o vírus está viável ou não ${ }^{(10,11)}$. Para isso, é realizado o isolamento viral, técnica considerada como o "padrão-ouro" no diagnóstico da influenza ${ }^{(12,13)}$. A obtenção do isolado viral permite a realização de estudos sobre diversidade genética viral, patogenia, caracterização antigênica e produção de candidatos vacinais ${ }^{(9,13)}$. Porém, para o sucesso do isolamento viral, é primordial que o vírus presente na amostra esteja viável ${ }^{(13,14)}$ e, neste caso, a amostra de escolha é a secreção nasal colhida de suínos durante a fase aguda da infecção ${ }^{(1,15)}$.

Os vírus influenza apresentam um envelope lipídico, portanto são sensíveis a mudanças no ambiente físico como temperatura, $\mathrm{pH}$ e salinidade ${ }^{(16)}$. Dessa forma, a manutenção inadequada das amostras biológicas, principalmente em condições de elevada temperatura, pode comprometer o diagnóstico pela inativação das partículas virais ${ }^{(1,17,18)}$. Para evitar a redução de título viral, aumentando as chances de isolamento viral, as amostras devem ser transportadas ao laboratório no menor 
tempo possível e mantidas refrigeradas $\left(4^{\circ} \mathrm{C}\right)^{(19,20)}$. O congelamento de amostras do vírus influenza a $-20{ }^{\circ} \mathrm{C}$ não é indicado, uma vez que os cristais de gelo formados nessa temperatura inativam o vírus ${ }^{(16,18,21)}$. Da mesma forma, a correta formulação do meio de manutenção de vírus deve ser observada, ou seja, o meio deve ser isotônico, conter estabilizantes (soro albumina bovina, gelatina, sacarose e outros), antimicrobianos e antifúngicos para reduzir a contaminação bacteriana e fúngica $^{(22,18,21,23)}$. De acordo com as recomendações descritas no Manual Terrestre da Organização Mundial de Saúde Animal (OIE) ${ }^{(22)}$, amostras biológicas de suínos devem ser armazenadas em meio de transporte a $4{ }^{\circ} \mathrm{C}$ e remetidas ao laboratório preferencialmente em até 48 horas ${ }^{(22)}$. Entretanto, em virtude da grande extensão do Brasil e, consequentemente da distância que existe entre as áreas de produção de suínos e os laboratórios de diagnóstico, nem sempre esse prazo é obedecido.

Com este estudo objetivou-se avaliar a viabilidade do vírus influenza submetido a diferentes condições de manutenção, como modo de acondicionamento, temperatura e período de armazenamento da amostra até o envio ao laboratório para diagnóstico.

\section{Material e Métodos}

Para os ensaios de viabilidade viral foi utilizada uma amostra do vírus influenza do subtipo H1N1/2009 isolada de suínos em 2010 na Embrapa Suínos e Aves (A/swine/Brazil/107/2010) ${ }^{(8)}$ e armazenada no CMISEA (Coleção de Microorganismos de Interesse para Suínos e Aves) sob o código BRMSA 00099. Para a realização do teste, a amostra viral foi multiplicada em ovos embrionados de galinhas SPF (Specific Pathogen Free) e, após duas passagens em ovos, apresentou título hemaglutinante de 1:128 e dose infectante em 50\% da cultura celular da linhagem MDCK (Madin-Darby Canine Kidney) de $1 \times 10^{4,38}$ por $\mathrm{mL}$.

Foram avaliados três modos de acondicionamento da amostra viral: um meio disponível comercialmente, meio UTM (Universal Transport Medium; Copan®), um meio produzido no laboratório de virologia da Embrapa Suínos e Aves, tendo como base o meio mínimo essencial (MEM) acrescido de antimicrobiano, antifúngico e albumina sérica bovina e aqui denominado VTM (Viral Transport Media) e a manutenção da amostra viral em frasco vazio, sem meio de manutenção. Para isto, suabes sintéticos (Inlab®) foram embebidos em $100 \mu \mathrm{L}$ da solução estoque do vírus por cinco minutos, armazenados em microtubos do tipo eppendorf de $2 \mathrm{~mL}$ e imediatamente submetidos às diferentes condições testadas. Para as amostras mantidas em meio de acondicionamento viral (UTM e VTM), $900 \mu \mathrm{L}$ de cada meio foi adicionado ao tubo correspondente. As amostras mantidas em frascos sem meio de acondicionamento foram acrescidas de $900 \mu \mathrm{L}$ de meio VTM ao final de cada período de armazenagem, mantendo a mesma diluição viral utilizada para os demais meios (1:10). As amostras virais, mantidas em UTM, VTM ou sem meio, foram incubadas a 4,23 e $37{ }^{\circ} \mathrm{C}$ por um período de até cinco dias (120 horas). Alíquotas das amostras foram colhidas a cada 12 horas e armazenadas a $-80^{\circ} \mathrm{C}$ para posterior análise (Figura 1). 

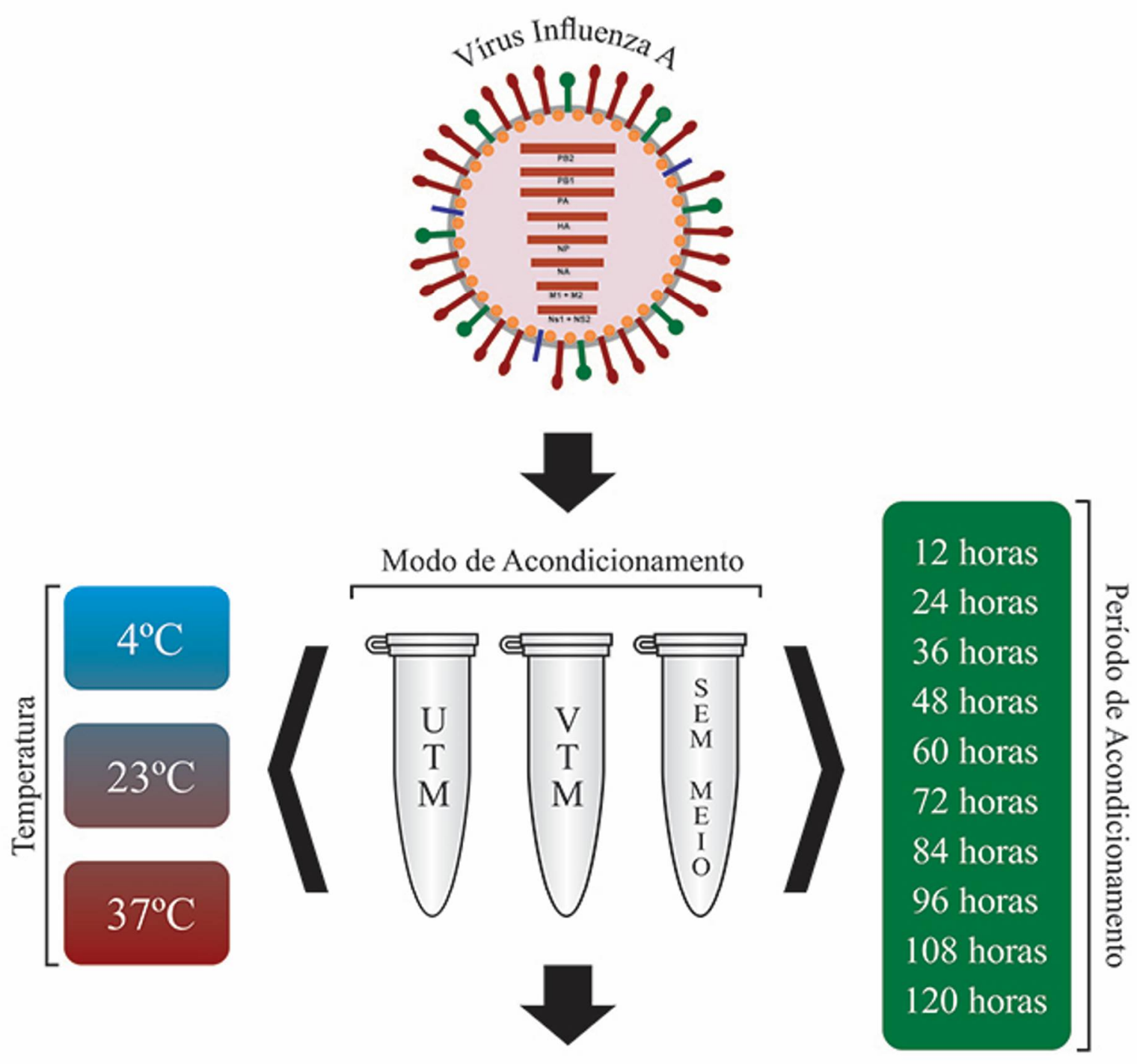

Isolamento viral em ovos SPF

\section{Teste de hemaglutinação}

\section{RT-PCR em tempo real quantitativa}

Figura 1. Desenho experimental utilizado para realizar a avaliação das condições de armazenamento (modo, temperatura e período de acondicionamento) do vírus Influenza H1N1/2009 no diagnóstico viral. (Vírus influenza A adaptado de Vincent et al.) ${ }^{(24)}$

Para testar a viabilidade viral de cada uma das amostras submetidas aos diferentes tratamentos, $600 \mu \mathrm{L}$ de cada amostra foram inoculados em três ovos SPF $\left(200 \mu \mathrm{L}\right.$ por ovo) com nove dias de incubação ${ }^{(13)}$. Após um período de incubação de quatro dias a $37^{\circ} \mathrm{C}$, o líquido cório-alantóide dos ovos foi colhido e submetido ao teste de hemaglutinação (HA) ${ }^{(25)}$ e RT-PCR em tempo real quantitativa (RT-qPCR) para confirmação da presença do vírus e quantificação da carga viral. Para a realização da RT-qPCR, o RNA viral foi extraído por beads magnéticas (MagMAX ${ }^{\mathrm{TM}}$, Ambion $\left.{ }^{\circledR}\right)$ e utilizados iniciadores e sonda previamente descritos $^{(10)}$ para amplificação do gene que codifica a proteína da matriz do 
FLUAV. Na reação foi usado o kit AgPath-ID OneStep (Ambion ${ }^{\circledR}$ ), o sistema de detecção TaqMan e o equipamento 7500 Real Time PCR System (Applied Biosystems ${ }^{\circledR}$ ). O ciclo de quantificação $(\mathrm{Cq})$, inversamente associado à carga viral foi determinado para cada amostra.

A análise da variância foi realizada para o modelo que considera os efeitos do modo, temperatura e período de acondicionamento e as interações duplas entre eles. A interação tripla foi considerada no modelo como efeito residual, uma vez que somente foi avaliada uma repetição para cada combinação dos níveis dos fatores avaliados. $O$ desdobramento dos efeitos significativos $(p<0,05)$ foi realizado por meio do teste de Tukey ${ }^{(26)}$. Devido à heterogeneidade de variâncias observada pela análise gráfica de resíduos e pelo teste de Levene, optou-se por realizar a análise da variância ponderando-se os dados pelo inverso da variância em cada combinação de modo e tempo de acondicionamento, uma vez que a heterocedasticidade estava associada aos níveis desses dois fatores.

\section{Resultados e Discussão}

A capacidade de recuperar vírus influenza viável, armazenado em diferentes condições de manutenção (modo, temperatura e período de acondicionamento) foi verificada pela inoculação das amostras virais em ovos SPF, após os diferentes tratamentos realizados. Todas as amostras foram positivas no teste de HA, apresentando título variando entre 1:2 e 1:64. Da mesma forma, todas as amostras avaliadas foram positivas para o FLUAV por RT-qPCR, confirmando que a integridade do RNA viral foi mantida em todas as condições testadas (modo, temperatura e período de acondicionamento). Os resultados do $\mathrm{Cq}$ viral em relação ao modo de acondicionamento e temperatura ao longo do período de até 120 horas são mostrados na Figura 2. Observou-se uma relação inversamente proporcional entre o $\mathrm{Cq}$ e a temperatura de acondicionamento (Figura 2 - a, c, e) e quando a amostra foi mantida sem meio de manutenção (Figura $2-b, d, f)$. Os resultados obtidos para o modo e período de acondicionamento e, também, para a interação entre esses dois fatores para o $\mathrm{Cq}$ (carga viral) foram estatisticamente significantes $(\mathrm{p}<0,05)$ quando avaliados pelo teste $\mathrm{F}$. Detalhes da interação entre meios de manutenção e tempo de armazenamento estão demonstrados na Figura 3. Como observado, é destacada a diferença nas grandezas dos erros-padrão (representados pelas linhas), sendo os erros-padrão do meio UTM muito inferiores aos outros dois modos de acondicionamento, além de manter as médias de Cq no decorrer do período de armazenamento, o que não ocorreu com os outros dois modos de acondicionamento. Não foram identificadas diferenças significativas entre o acondicionamento sem meio de manutenção e os outros dois meios, quando os resultados foram analisados pelo teste de Tukey, provavelmente porque os erros-padrão desse tratamento foram muito elevados. As médias do meio de acondicionamento UTM diferiram significativamente das médias do meio VTM nos tempos 60, 72 e 108 horas de armazenamento. A capacidade de detecção do FLUAV por RT-qPCR em amostras de suabes nasais mantidas sob diferentes condições em intervalos de 24 horas foram estudadas por Druce et al. ${ }^{(17)}$ que observaram resultados similares nas amostras acondicionadas sem meio de manutenção. Contudo, o trabalho citado avaliou somente a integridade do RNA viral, não avaliando a infectividade viral. 


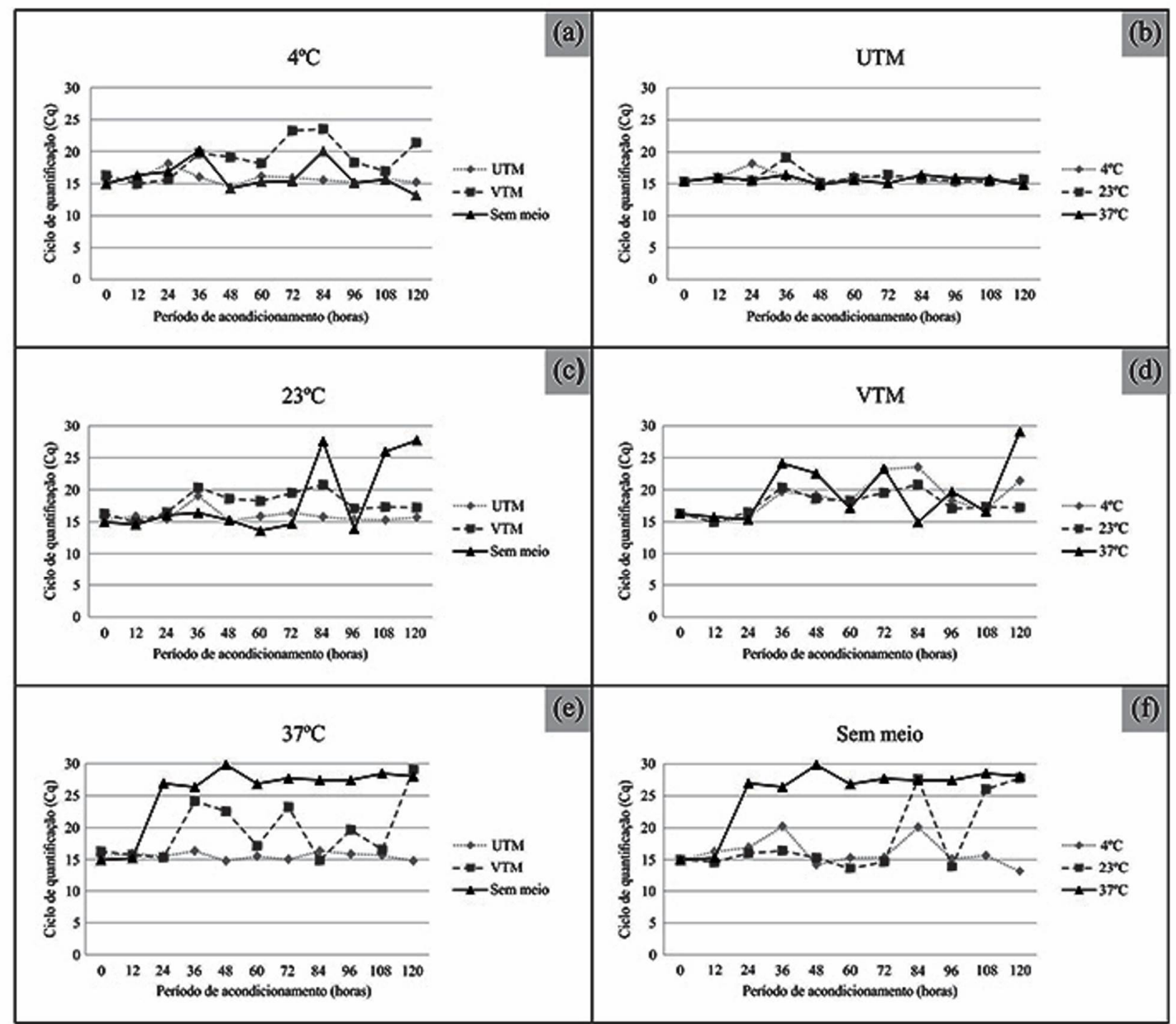

Figura 2. Avaliação do ciclo de quantificação $(\mathrm{Cq})$, inversamente associado à carga viral, em relação à temperatura $\left(4,23\right.$ e $\left.37^{\circ} \mathrm{C}\right)(\mathrm{a}, \mathrm{c}, \mathrm{e})$ e ao modo de acondicionamento (UTM, VTM e sem meio) (b, d, f), de acordo com o tempo de armazenamento ( 0 a 120 horas).

O sucesso no isolamento viral e manutenção quase constante da carga viral observados neste estudo para os diferentes tratamentos, possivelmente foram devidos à elevada carga viral inicial, uma vez que a amostra viral utilizada foi previamente multiplicada em ovos SPF. Assim, para aumentar as chances de isolamento viral, a colheita das amostras biológicas a campo deve ser realizada durante o pico da excreção viral do FLUAV, durante a fase aguda da infecção (primeiros cinco a sete dias pósinfecção) $)^{(23,27)}$.

Nossos resultados corroboram com as recomendações da $\mathrm{OIE}^{(22)}$, demonstrando que a integridade do RNA viral e a viabilidade viral são mantidas se as amostras biológicas forem enviadas ao laboratório de diagnóstico em tempo hábil e armazenadas adequadamente. 


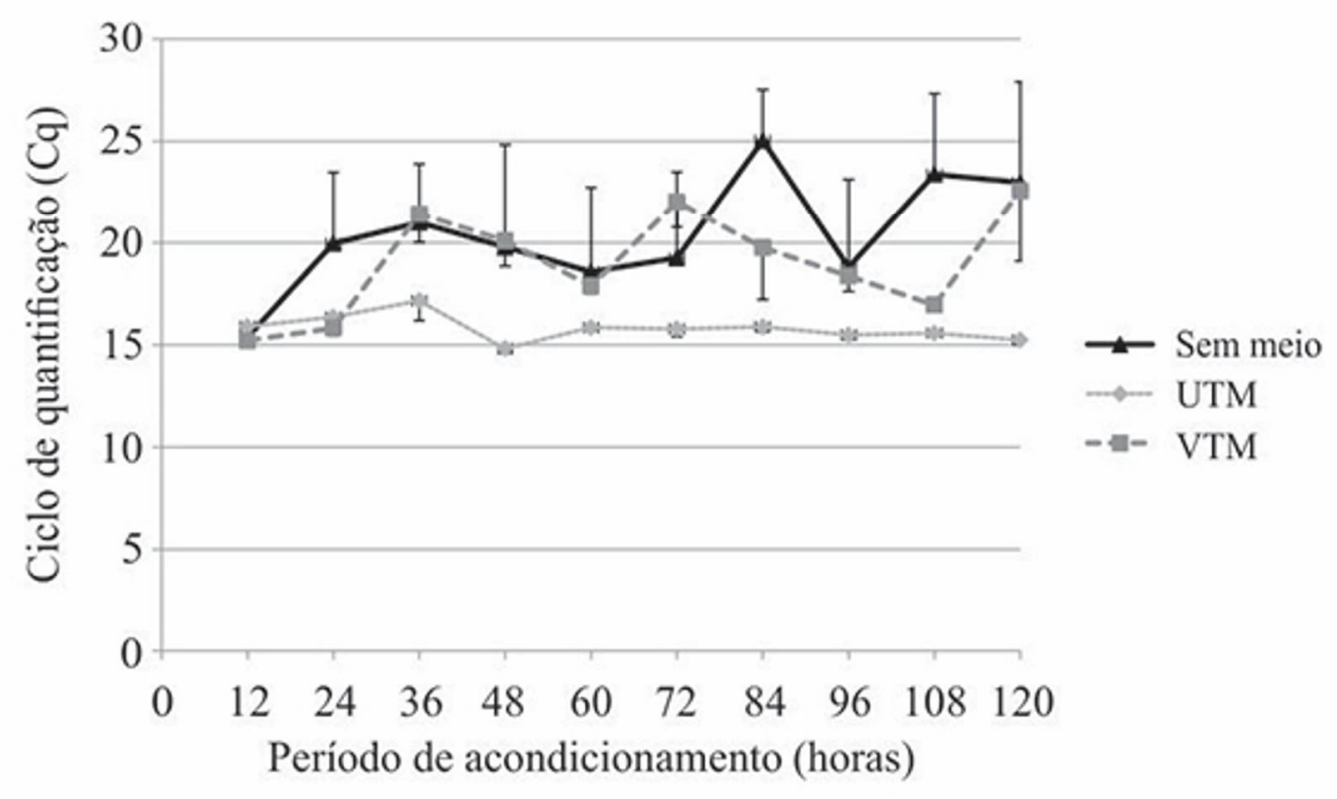

Figura 3. Médias e erros-padrão do ciclo de quantificação (Cq) em função das combinações entre meios de manutenção e tempo de armazenamento.

\section{Conclusão}

Com os resultados obtidos, recomenda-se que as amostras biológicas encaminhadas para diagnóstico de FLUAV sejam, preferencialmente, armazenadas em meio de manutenção de vírus, mantidas a $4{ }^{\circ} \mathrm{C}$, e que o tempo decorrido entre a colheita da amostra e a chegada ao laboratório de diagnóstico seja de, no máximo, três dias.

\section{Agradecimentos}

Ao Conselho Nacional de Desenvolvimento Científico e Tecnológico (CNPq) pela concessão de bolsa de iniciação científica à Vanessa Haach e à EMBRAPA pelo suporte financeiro. À Marina Schmitt pelo design gráfico.

\section{Referências}

1. Van Reeth K, Brown IH, Olsen CW. Influenza Virus. In: Zimmerman JJ, Karriker LA, Ramirez A, Schwartz 
KJ, Stevenson GW, editors. Diseases of Swine. 10th ed. Ames: Iowa State University Press; 2012. p.557-571.

2. Vincent A, Awada L, Brown I, Chen H, Claes F, Dauphin G, Donis R, Culhane M, Hamilton K, Lewis N, Mumford E, Nguyen T, Parchariyanon S, Pasick J, Pavade G, Pereda A, Peiris M, Saito T, Swenson S, Van Reeth K, Webby R, Wong F, Ciacci-Zanella, J. Review of influenza A virus in swine worldwide: a call for increased surveillance and research. Zoonoses and Public Health. 2014;61(1):4-17.

3. Cunha RG, Vinha VR, Passos WD. Isolation of a strain of Myxovirus influenzae-A suis from swine slaughtered in Rio de Janeiro. Revista Brasileira de Biologia. 1978;38(1):13-17.

4. Brentano L, Ciacci-Zanella JR, Mores N, Piffer IA. Levantamento soroepidemiológico para Coronavírus Respiratório e da Gastroenterite Transmissível e dos Vírus de Influenza H3N2 e H1N1 em rebanhos suínos no Brasil. Comunicado Técnico, Embrapa Suínos e Aves, Concórdia. 2002:1-6. Português.

5. Schaefer R, Zanella JRC, Brentano L, Vincent AL, Ritterbusch GA, Silveira S, Caron L, Mores N. Isolation and characterization of a pandemic H1N1 influenza virus in pigs in Brazil. Pesquisa Veterinária Brasileira. 2011;31(9):761-767.

6. Rajão DS, Costa ATR, Brasil BSAF, Del Puerto HL, Oliveira FG, Alves F, Braz GF, Reis JKP, Guedes RMC, Lobato ZIP, Leite RC. Genetic characterization of influenza virus circulating in Brazilian pigs during 2009 and 2010 reveals a high prevalence of the pandemic H1N1 subtype. Influenza and Other Respiratory Viruses. 2013;7(5):783-790.

7. Ciacci-Zanela JR, Schaefer R, Gava D, Haach V, Cantão ME, Coldebella A. Influenza A virus infection in Brazilian swine herds following the introduction of pandemic 2009 H1N1. Veterinary Microbiology. 2015;180(1-2):118-122.

8. Nelson MI, Schaefer R, Gava D, Cantão ME, Ciacci-Zanella JR. Influenza A viruses of human origin swine, Brazil. Emerging and Infectious Diseases. 2015;21(8):1339-1347.

9. Janke BH. Influenza A virus infections in swine: pathogenesis and diagnosis. Veterinary Pathology. 2014;51(2):410-426.

10. Zhang J, Harmon KM. RNA extraction from swine samples and detection of influenza A virus in swine by real-time RT-PCR. Methods in Molecular Biology. 2014;1161:277-293.

11. Detmer S, Gramer M, Goyal S, Torremorell M, Torrison J. Diagnostics and surveillance for swine influenza. Current Topics in Microbiology and Immunology. 2013;370:85-112.

12. Swenson SL, Vincent LL, Lute BM, Janke BH, Lechtenberg KE, Landgraf JG, Schmitt BJ, Kinker DR, McMillen JK. A comparison of diagnostic assays for the detection of type A swine influenza virus from nasal swabs and lungs. Journal of Veterinary Diagnostic Investigation. 2001;13(1):36-42.

13. Zhang J, Gauger PC. Isolation of swine influenza virus in cell cultures and embryonated chicken eggs. Methods in Molecular Biology. 2014;1161:265-276.

14. Zhang J, Gauger PC, Harmon K. Swine influenza A virus. In: Liu D, editor. Molecular Detection of Animal Viral Pathogens. Boca Raton: CRC Press; 2016. p.399-406.

15. Schaefer R, Rech RR, Silva MC, Gava D, Ciacci-Zanella JR. Orientações para o diagnóstico de influenza em suínos. Pesquisa Veterinária Brasileira. 2013;33(1):61-73. Português.

16. Latorre-Margalef N, Avril A, Tolf C, Olsen B, Waldenström J. How does sampling methodology influence molecular detection and isolation success in influenza A virus field studies? Applied and Environmental Microbiology. 2015;82(4):1147-1153.

17. Druce J, Garcia K, Tran T, Papadakis G, Birch C. Evaluation of swabs, transport media, and specimen transport conditions for optimal detection of virus by PCR. Journal of Clinical Microbiology. 2012;50(3):1064-

Cienc. anim. bras., Goiânia, v.19, 1-9, e-46789, 2018 
1065.

18. Jonhson FB. Transport of viral specimens. Clinical Microbiology Reviews. 1990;3(2):120-131.

19. Schlaudecker EP, Heck JP, MacIntyre ET, Martinez R, Dodd CN, McNeal MM, Staat MA, Heck JE, Steinhoff MC. Comparison of a new transport medium with universal transport medium at a tropical field site. Diagnostic Microbiology and Infectious Disease. 2014;80(2):107-110.

20. Culhane MR, Detmer SE. Sample types, collection, and transport for influenza A viruses of swine. Methods in Molecular Biology. 2014;1161:259-264.

21. Zhang XC, Liu S, Hou GY, Zhuang QY, Wang KC, Jiang WM, Wang SC, Li JP, Yu JM, Du X, Huang BX, Chen JM. Comparison of three media for transport and storage of the samples collected for detection of avian influenza virus. Journal of Virological Methods. 2015;222:202-205.

22. OIE - OIE Terrestrial Manual. 2016. [cited 2017 fev 06]. Available from: http://www.oie.int/internationalstandard-setting/terrestrial-manual/access-online/

23. Dunn JJ, Billetdeaux E, Skodack-Jones L, Carroll KC. Evaluation of three Copan viral transport systems for the recovery of cultivatable, clinical virus isolates. Diagnostic Microbiology and Infectious Disease. 2003;45(3):191-197.

24. Vincent AL, Ma W, Lager KM, Janke BH, Richt JA. Swine influenza viruses: A North American perspective. Advances in Virus Research. 2008;72:127-154.

25. Killian ML. Hemagglutination assay for influenza virus. Methods in Molecular Biology. 2014;1161:3-9.

26. SAS Institute Inc. System for Microsoft Windows, Release 9.4, Cary, NC, USA, 2002-2012 (cd-rom).

27. Esposito S, Molteni CG, Daleno C, Valzano A, Cesati L, Gualtieri L, Tagliabue C, Bosis S, Principi N. Comparison of nasopharyngeal nylon flocked swabs with universal transport medium and rayon-bud swabs with a sponge reservoir of viral transport medium in the diagnosis of paediatric influenza. Journal of Medical Microbiology. 2010;59:96-99. 